\begin{tabular}{|c|l|}
\hline Title & Theoretical investigations on hydrogen peroxide decomposition in aquo \\
\hline Author(s) & Tsuneda, Takao; Taketsugu, Tetsuya \\
\hline Citation & $\begin{array}{l}\text { Physical chemistry chemical physics, 20(38), 24992-24999 } \\
\text { https://doi.org/10.1039/c8cp04299c }\end{array}$ \\
\hline Issue Date & 2018-10-14 \\
\hline Doc URL & http://hdl.handle.net/2115/75761 \\
\hline Type & article (author version) \\
\hline File Information & paper.pdf \\
\hline
\end{tabular}

Instructions for use 


\title{
Theoretical investigations on hydrogen peroxide decomposition in aquo
}

\author{
Takao Tsuneda ${ }^{1,2 *}$ and Tetsuya Taketsugu ${ }^{2}$ \\ ${ }^{1}$ Fuel Cell Nanomaterials Center, University of Yamanashi, Kofu 400-0021, Japan and \\ ${ }^{2}$ Department of Chemistry, Faculty of Science, \\ Hokkaido University, Sapporo 060-0810, Japan
}

\begin{abstract}
Hydrogen peroxide $\left(\mathrm{H}_{2} \mathrm{O}_{2}\right)$ decomposition mechanisms under the absence and presence of iron ions in aqueous solution, which contain no $\mathrm{OH}$ radical formations, are theoretically determined. Calculating the oxygen-oxygen bond dissociation energies of $\mathrm{H}_{2} \mathrm{O}_{2}$, we confirmed that the $\mathrm{OH}$ radical formation requires spin-forbidden transitions. Instead, we tested an $\mathrm{H}_{2} \mathrm{O}_{2}$ dimer-based decomposition mechanism and found that this mechanism provides reasonable barrier heights with $52 \sim 62 \mathrm{kcal} / \mathrm{mol}$, which are close to the experimental activation energy. We next calculated the oxygen-oxygen bond dissociation of $\mathrm{H}_{2} \mathrm{O}_{2}$ coordinating to the iron ion hydration complex in order to explore the $\mathrm{H}_{2} \mathrm{O}_{2}$ decomposition under the presence of iron ions. Surprisingly, we found that a monovalent iron ion complex provides no reaction barrier to dissociate $\mathrm{H}_{2} \mathrm{O}_{2}$, in contrast to the ferrous $\left(\mathrm{Fe}^{2+}\right)$ and ferric $\left(\mathrm{Fe}^{3+}\right)$ ion complexes accompanying very high barriers. Following this result, we determined the subsequent oxygen formation mechanism of the monovalent iron ion complex and found that this mechanism needs a hydrogen bond network around $\mathrm{H}_{2} \mathrm{O}_{2}$ to proceed at room temperature. We, therefore, conclude that the $\mathrm{H}_{2} \mathrm{O}_{2}$ decomposition under the presence of iron ions is driven by the electron transfer to the iron ion hydration complex and proceeds by hydrogen transfers in the hydrogen bond network around $\mathrm{H}_{2} \mathrm{O}_{2}$.
\end{abstract}




\section{INTRODUCTION}

Hydrogen peroxide $\left(\mathrm{H}_{2} \mathrm{O}_{2}\right)$ decomposition is frequently used as an efficient method for testing the durability of materials. For many materials, $\mathrm{H}_{2} \mathrm{O}_{2}$ is known as the main cause for the degradation, as found in, e.g., proton exchange membranes of fuel cells under the operation. Metal ions such as divalent iron (ferrous) and divalent manganese ions are wellknown to decompose $\mathrm{H}_{2} \mathrm{O}_{2} \cdot{ }^{1,2}$ In Fenton test, ${ }^{3}$ these ions are, therefore, used with $\mathrm{H}_{2} \mathrm{O}_{2}$ as reagents for degrading materials. Hydroxyl $(\mathrm{OH})$ radicals have been taken as the main species for the decomposition in aqueous solution:

$$
\begin{aligned}
\mathrm{H}_{2} \mathrm{O}_{2} & \rightarrow 2 \mathrm{OH} \\
\mathrm{H}_{2} \mathrm{O}_{2}+\mathrm{OH} & \rightarrow \mathrm{HO}_{2}+\mathrm{H}_{2} \mathrm{O} \\
2 \mathrm{HO}_{2} & \rightarrow \mathrm{H}_{2} \mathrm{O}_{2}+\mathrm{O}_{2}
\end{aligned}
$$

The ferrous ion-induced $\mathrm{H}_{2} \mathrm{O}_{2}$ decomposition has also been interpreted to proceed through the $\mathrm{OH}$ radical production. Haber and Weiss experimentally suggested an $\mathrm{H}_{2} \mathrm{O}_{2}$ decomposition mechanism by ferrous cation $\left(\mathrm{Fe}^{2+}\right):^{4}$

$$
\begin{aligned}
\mathrm{Fe}^{2+}+\mathrm{H}_{2} \mathrm{O}_{2} & \rightarrow \mathrm{Fe}^{3+}+\mathrm{OH}+\mathrm{OH}^{-} \\
\mathrm{Fe}^{2+}+\mathrm{OH} & \rightarrow \mathrm{Fe}^{3+}+\mathrm{OH}^{-} \\
\mathrm{H}_{2} \mathrm{O}_{2}+\mathrm{OH} & \rightarrow \mathrm{HO}_{2}+\mathrm{H}_{2} \mathrm{O} \\
\mathrm{HO}_{2}+\mathrm{H}_{2} \mathrm{O}_{2} & \rightarrow \mathrm{O}_{2}+\mathrm{H}_{2} \mathrm{O}+\mathrm{OH}
\end{aligned}
$$

Since the pKa value of $\mathrm{HO}_{2}$ in Eq. (6) is $4.88,{ }^{5} \mathrm{HO}_{2}$ is considered to dissociate proton to produce $\mathrm{O}_{2}^{-}$in neutral water, i.e.,

$$
\mathrm{HO}_{2} \rightarrow \mathrm{H}^{+}+\mathrm{O}_{2}^{-}
$$

The reaction of $\mathrm{HO}_{2}$ and $\mathrm{OH}$ radicals is, therefore, often included in the mechanism as an $\mathrm{O}_{2}$ formation process, i.e.,

$$
\mathrm{OH}+\mathrm{HO}_{2} \rightarrow \mathrm{O}_{2}+\mathrm{H}_{2} \mathrm{O}
$$

Moreover, Barb et al. replaced Eq. (7) with the following equations in another $\mathrm{Fe}^{2}$-induced decomposition mechanism: ${ }^{6,7}$

$$
\begin{aligned}
& \mathrm{Fe}^{2+}+\mathrm{HO}_{2} \rightarrow \mathrm{Fe}^{3+}+\mathrm{HO}_{2}^{-}, \\
& \mathrm{Fe}^{3+}+\mathrm{HO}_{2} \rightarrow \mathrm{Fe}^{2+}+\mathrm{H}^{+}+\mathrm{O}_{2} .
\end{aligned}
$$


In total, these equations are expressed as

$$
2 \mathrm{Fe}^{2+}+3 \mathrm{H}_{2} \mathrm{O}_{2} \rightarrow 2 \mathrm{Fe}^{3+}+2 \mathrm{OH}^{-}+2 \mathrm{H}_{2} \mathrm{O}+\mathrm{O}_{2}
$$

Based on this equation, the Fenton test ${ }^{3}$ has been explained to produce $\mathrm{OH}$ radicals, which decompose $\mathrm{H}_{2} \mathrm{O}_{2}$. Note, however, that the lifetime of $\mathrm{OH}$ radicals is known to be only $10^{-7} \mathrm{~s}$ (100 ns) in aqueous solution, though it is $1 \mathrm{~ms}$ in gas phase. The lifetime in aquo is too short to initiate the degradation of polymer membranes. It is, therefore, reasonable to consider that there is another reaction pathway to decompose $\mathrm{H}_{2} \mathrm{O}_{2}$ without producing $\mathrm{OH}$ radicals.

Prior to the $\mathrm{OH}$ radical-production mechanism, Bray and Gorin experimentally proposed another $\mathrm{H}_{2} \mathrm{O}_{2}$ decomposition mechanism proceeding through the production of divalent iron oxide cation $\left(\mathrm{FeO}^{2+}\right):^{8}$

$$
\begin{gathered}
\mathrm{Fe}^{2+}+\mathrm{H}_{2} \mathrm{O}_{2} \rightarrow \mathrm{FeO}^{2+}+\mathrm{H}_{2} \mathrm{O}, \\
\mathrm{FeO}^{2+}+\mathrm{H}_{2} \mathrm{O}_{2} \rightarrow \mathrm{Fe}^{2+}+\mathrm{O}_{2}+\mathrm{H}_{2} \mathrm{O}
\end{gathered}
$$

However, $\mathrm{FeO}^{2+}$ had not been considered to play a significant role in the $\mathrm{H}_{2} \mathrm{O}_{2}$ decomposition for many years, because it appears to be too inactive to degrade materials. Baerends and coworkers theoretically investigated this $\mathrm{FeO}$ formation mechanism in the following equations: ${ }^{9}$

$$
\begin{aligned}
{\left[\left(\mathrm{H}_{2} \mathrm{O}\right)_{5} \mathrm{Fe}\left(\mathrm{H}_{2} \mathrm{O}_{2}\right)\right]^{2+} } & \rightarrow\left[\left(\mathrm{H}_{2} \mathrm{O}\right)_{4} \mathrm{Fe}(\mathrm{OH})_{2}\right]^{2+}+\mathrm{H}_{2} \mathrm{O} \\
{\left[\left(\mathrm{H}_{2} \mathrm{O}\right)_{4} \mathrm{Fe}(\mathrm{OH})_{2}\right]^{2+} } & \rightarrow\left[\left(\mathrm{H}_{2} \mathrm{O}\right)_{5} \mathrm{FeO}\right]^{2+} .
\end{aligned}
$$

These equations contain no $\mathrm{OH}$ radical formation, and instead, require the hydrogen transfer between oxygen atoms. In the present calculations, this hydrogen transfer provides a very high barrier height, which is inconsistent with the original result, ${ }^{9}$ as mentioned later. Note also that they studied no subsequent mechanism after the FeO formation. Cannot this FeO formation mechanism substitute for the $\mathrm{OH}$ radical mechanism in the ferrous ion-induced $\mathrm{H}_{2} \mathrm{O}_{2}$ decomposition?

A recent experimental study shows that $\mathrm{FeO}$ is produced in the $\mathrm{H}_{2} \mathrm{O}_{2}$ decomposition and $\mathrm{OH}$ radicals hardly contribute to the $\mathrm{H}_{2} \mathrm{O}_{2}$ decomposition. Enami et al. performed a mass spectroscopy experiment of aqueous microjet containing iron(II) chloride $\left(\mathrm{FeCl}_{2}\right)$ for selectively observing low-concentrated compounds produced at aqueous interfaces with very short time scale $\left(<5 \times 10^{-5}\right.$ s). ${ }^{10}$ As a result, they found that the $\mathrm{H}_{2} \mathrm{O}_{2}$ decomposition 
reactions at the interfaces proceed $1,000 \sim 10,000$ times faster than those in aquo. Their results also indicate that the $\mathrm{Fe}^{2+}$ ion-induced $\mathrm{H}_{2} \mathrm{O}_{2}$ decomposition takes place as follows:

1. $\mathrm{OH}$ radicals hardly contribute to the decomposition, because an $\mathrm{OH}$ radical scavenger (tertiary butanol, t-BuOH) hardly affects the mass spectra,

2. $\mathrm{FeO}$ and $\mathrm{Fe}^{3+}$ are produced in the decomposition, because the mass spectrum peaks corresponding to these species appear, and

3. $\mathrm{H}_{2} \mathrm{O}_{2}$ may replace with a coordinated $\mathrm{H}_{2} \mathrm{O}$ to initiate the decomposition, because the decomposition reaction rate is very fast at the interfaces.

These conclusions disprove conventional $\mathrm{H}_{2} \mathrm{O}_{2}$ decomposition mechanisms including $\mathrm{OH}$ productions and also indicate the significance of the decomposition mechanism through the FeO formation. As far as we know, the $\mathrm{H}_{2} \mathrm{O}_{2}$ decomposition reaction pathway through the $\mathrm{FeO}$ formation is not yet theoretically revealed. Elucidating this $\mathrm{H}_{2} \mathrm{O}_{2}$ decomposition mechanism will advance the understanding of the catalytic reactions by metal clusters.

In this study, $\mathrm{H}_{2} \mathrm{O}_{2}$ decomposition mechanisms are theoretically revealed for the reactions under the presence or absence of iron ions following the recent experimental findings. The theoretical calculations assumed that the iron ion-induced decompositions are driven by the replacement of a coordinated $\mathrm{H}_{2} \mathrm{O}$ with $\mathrm{H}_{2} \mathrm{O}_{2}$ and contain the $\mathrm{FeO}$ formation without $\mathrm{OH}$ radical productions.

\section{COMPUTATIONAL DETAILS}

Calculations have been performed using the hydrated $\mathrm{H}_{2} \mathrm{O}_{2}$ monomer and dimer models, hydrated with $2,4,6$, and 8 water molecules, and the hydrated iron ion model, in which $\left[\mathrm{Fe}\left(\mathrm{H}_{2} \mathrm{O}_{2}\right)\left(\mathrm{H}_{2} \mathrm{O}\right)_{5}\right]^{n+}$ complex for $n=1$ and 2 is used with two additional hydration $\mathrm{H}_{2} \mathrm{O}$ molecules (Fig. 1). These model structures are determined by maximizing the number of hydrogen bonds and then selecting the minimum energy geometries in the several similar isomers. For these models, reactant, product and transition state (TS) calculations have been carried out to construct the reaction energy diagrams by the Kohn-Sham calculations ${ }^{11,12}$ using the long-range correction ${ }^{13,14}$ of Becke 1988 exchange $^{15}$ plus Lee-Yang-Parr correlation ${ }^{16}$ (LC-BLYP) functional (the only parameter $\mu=0.33^{17}$ ). Note that the high reliability 
(a)

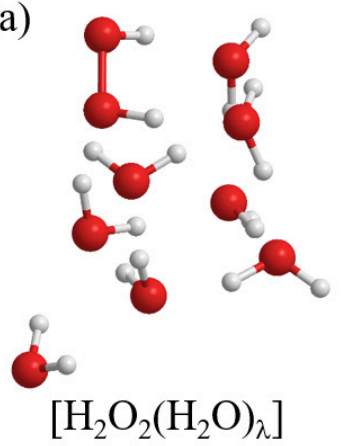

(c)

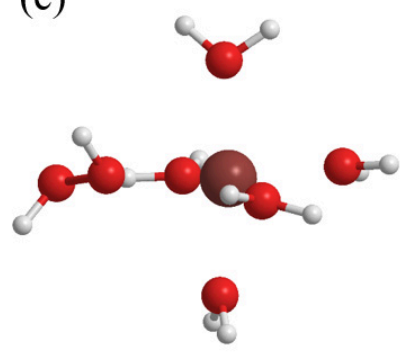

$\left[\mathrm{Fe}\left(\mathrm{H}_{2} \mathrm{O}_{2}\right)\left(\mathrm{H}_{2} \mathrm{O}\right)_{5}\right]^{\mathrm{n}+}$

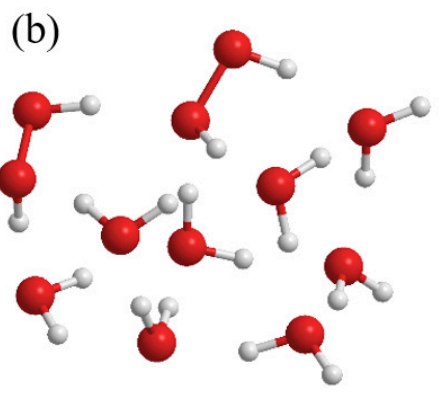

$\left[\left(\mathrm{H}_{2} \mathrm{O}_{2}\right)_{2}\left(\mathrm{H}_{2} \mathrm{O}\right)_{\lambda}\right]$

(d)

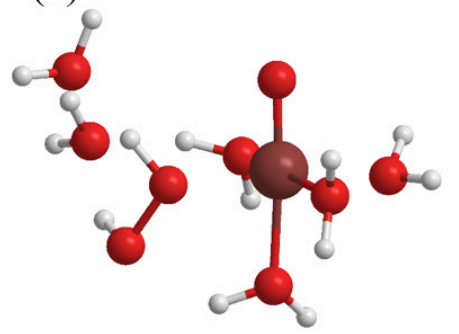

$\left[\mathrm{FeO}\left(\mathrm{H}_{2} \mathrm{O}_{2}\right)\left(\mathrm{H}_{2} \mathrm{O}\right)_{5}\right]^{\mathrm{n}+}\left(\mathrm{H}_{2} \mathrm{O}\right)_{2}$

FIG. 1: Calculation models of (a) hydrated $\mathrm{H}_{2} \mathrm{O}_{2}$ monomer with $\lambda$ hydration water molecules $\left(\left[\left(\mathrm{H}_{2} \mathrm{O}_{2}\right)_{2}\left(\mathrm{H}_{2} \mathrm{O}\right)_{\lambda}\right]\right)$, (b) hydrated $\mathrm{H}_{2} \mathrm{O}_{2}$ dimer with $\lambda$ hydration water molecules $\left(\left[\left(\mathrm{H}_{2} \mathrm{O}_{2}\right)_{2}\left(\mathrm{H}_{2} \mathrm{O}\right)_{\lambda}\right]\right)$, (c) iron ion $\left(\mathrm{Fe}^{n+}\right)$ hydration complexes with $\lambda$ coordinating water molecules $\left(\left[\mathrm{Fe}\left(\mathrm{H}_{2} \mathrm{O}_{2}\right)\left(\mathrm{H}_{2} \mathrm{O}\right)_{5}\right]^{n+}\right)$, and $(\mathrm{d})$ iron oxide ion $\left(\mathrm{FeO}^{n+}\right)$ hydration complexes with $\lambda$ coordinating water molecules and two additional water molecules $\left(\left[\mathrm{FeO}\left(\mathrm{H}_{2} \mathrm{O}_{2}\right)\left(\mathrm{H}_{2} \mathrm{O}\right)_{5}\right]^{n+}\left(\mathrm{H}_{2} \mathrm{O}\right)_{2}\right)$.

of this method has been confirmed in the previous calculations of related systems: e.g., the $\mathrm{H}_{2} \mathrm{O}_{2}$-induced degradation of hydrated Nafion membrane ${ }^{18}$ and $\mathrm{H}_{2} \mathrm{O}_{2}$ decomposition by triphenylphosphine oxide. ${ }^{19}$ The cc-pVDZ basis set ${ }^{20,21}$ was used for $\mathrm{H}$ and $\mathrm{O}$ atoms and LANL2DZ effective core potential basis set ${ }^{22}$ was employed for Fe atom. As a solvent effect, the polarizable continuum model ${ }^{23}$ of water has been included. Transition state calculations have been performed by the quadratic synchronous transit method ${ }^{24,25}$ using several initial structures for finding out the minimum energy pathways. The intrinsic reaction coordinate (IRC) calculations ${ }^{26}$ have also been performed by the predictor-corrector integrator $\operatorname{method}^{27,28}$ for all the TS structures to confirm the correctness of these TS structures. In the O-O dissociation calculations of $\mathrm{H}_{2} \mathrm{O}_{2}$, the stability conditions for spin-restricted KohnSham calculations are attached to switch to the spin-unrestricted ones for spin-unstable 
electronic states in order to avoid the instability of single-configurational DFT calculations for bond dissociations. ${ }^{29,30}$ The Gaussian 09 suite of program ${ }^{31}$ has been used to perform all of the LC-BLYP calculations. All of the optimized structures have been checked to ensure that they yield positive, real frequencies. The calculated IRCs have been analysed using GaussView 5.0.8. ${ }^{32}$

\section{RESULTS AND DISCUSSION}

\section{A. $\mathrm{H}_{2} \mathrm{O}_{2}$ decomposition mechanism without metal ions}

First, we explored the $\mathrm{H}_{2} \mathrm{O}_{2}$ decomposition mechanism without metal ions in aqueous solution. The $\mathrm{OH}$ radical formation mechanism, $\mathrm{H}_{2} \mathrm{O}_{2} \rightarrow 2 \mathrm{OH}$, has been the most accepted $\mathrm{H}_{2} \mathrm{O}_{2}$ decomposition mechanism, ${ }^{33-37}$ because the dissociation energy of $\mathrm{H}_{2} \mathrm{O}_{2}$ into $\mathrm{OH}$ radicals is evaluated as about $50 \mathrm{kcal} / \mathrm{mol}$ (e.g., $54.8 \mathrm{kcal} / \mathrm{mol}$ for $\mathrm{H}_{2} \mathrm{O}_{2}$ with no explicitly-bonded $\mathrm{H}_{2} \mathrm{O}$ molecules in aqueous solution in the present calculation), while this energy is close to the experimentally-evaluated activation energy of the $\mathrm{H}_{2} \mathrm{O}_{2}$ decomposition without metal ions in aqueous solution, $47.8 \mathrm{kcal} / \mathrm{mol} .^{34,35,38}$ Figure 2 illustrates the O-O dissociation potential energy curves for the hydration numbers $\lambda=0,2,4,6$, and 8 with the solvent effect. As shown in the figure, the O-O dissociations asymptotically approach the dissociation energies independently of the hydration numbers, in aqueous solution. Note, however, that the produced $\mathrm{OH}$ radicals rapidly recombine to form $\mathrm{H}_{2} \mathrm{O}_{2}$ under the hydrogen bond network, if the O-O dissociation proceeds with maintaining the singlet state. Actually, no subsequent potential energy curves is given for the longer O-O distances than $3 \AA$, because $\mathrm{H}_{2} \mathrm{O}_{2}$ is reproduced for the long O-O distances by hydrogen transfers in the hydrogen bond networks. Therefore, the spin multiplicity should be switched to the triplet state to maintain $\mathrm{OH}$ radicals. Though this spin flip takes place by spin-orbit transfers, it essentially needs very long time to proceed for such light atoms. We, therefore, consider that $\mathrm{H}_{2} \mathrm{O}_{2}$ is usually immediately recovered even if $\mathrm{OH}$ radicals are produced by the $\mathrm{O}-\mathrm{O}$ dissociations.

Regardless of the presence or absence of $\mathrm{OH}$ radicals, the $\mathrm{H}_{2} \mathrm{O}_{2}$ decomposition stoichiometrically requires two $\mathrm{H}_{2} \mathrm{O}_{2}$ molecules, as shown in Eqs. $(1) \sim(3)$ and in Eqs. $(13) \sim(14)$. Considering the instability of $\mathrm{OH}$ radicals, it is, therefore, reasonable to assume that the $\mathrm{H}_{2} \mathrm{O}_{2}$ decomposition takes place by the association of $\mathrm{H}_{2} \mathrm{O}_{2}$ molecules. Figure 3 shows the 


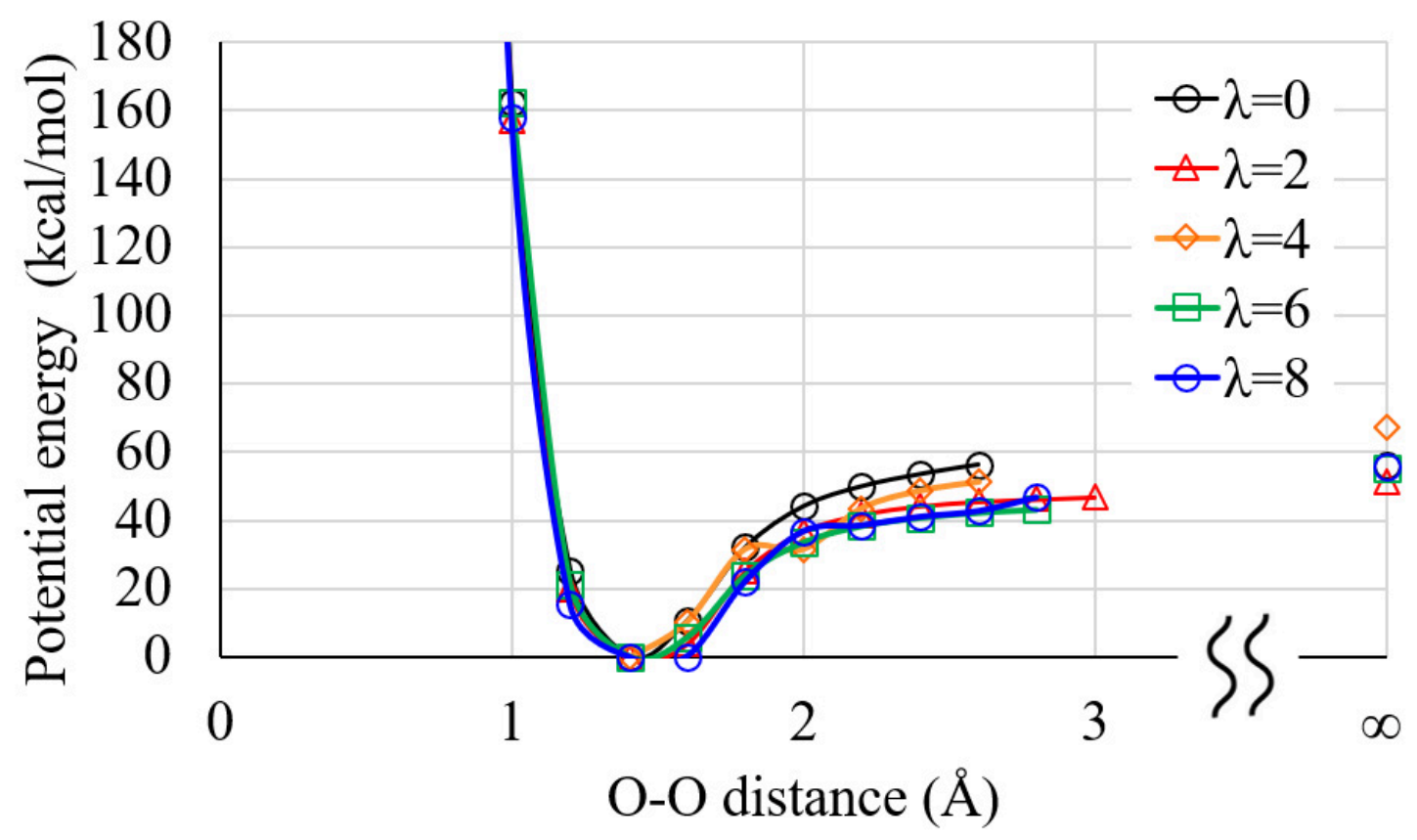

FIG. 2: Potential energy curves of the O-O dissociation of $\mathrm{H}_{2} \mathrm{O}_{2}$ to $\mathrm{OH}$ radicals for the explicit hydration numbers $\lambda=0,2,4,6$, and 8 in aqueous solution. The spin-restricted Kohn-Sham calculations are performed under the stability condition for switching to the spin-unrestricted ones. ${ }^{29,30}$ LC-BLYP/cc-pVDZ is used with the solvent effect of the polarizable continuum model of water. The minimum potential energies are set to be zero. The dissociation limit energies, which are calculated by equally dividing the hydrated $\mathrm{H}_{2} \mathrm{O}_{2}$ such as $\mathrm{H}_{2} \mathrm{O}_{2}\left(\mathrm{H}_{2} \mathrm{O}\right)_{2 \lambda} \rightarrow 2 \mathrm{OH}\left(\mathrm{H}_{2} \mathrm{O}\right)_{\lambda}$, are also shown at the infinite O-O distance.

reaction energy diagrams of the decomposition of the hydrated $\mathrm{H}_{2} \mathrm{O}_{2}$ dimer for the hydration numbers $\lambda=0,2,4,6$, and 8. For comprehension, the $\mathrm{H}_{2} \mathrm{O}_{2}$ dimer structures of $\lambda=0$ (no explicitly-coordinated hydration water molecule) are shown for five reaction steps, though they are different from those of other hydration numbers except for the synthetic species (see Fig. S1 of the supporting information): $\mathrm{H}_{2} \mathrm{O}_{3}(\mathrm{OHOHO})$ radical is produced in the first step and $\mathrm{O}_{2}$ and $\mathrm{H}_{2} \mathrm{O}$ are synthesized in the second step. Note that this OHOHO radical is different from $\mathrm{HOOOH}$ radical, which is also considered to produce $\mathrm{O}_{2}$ with small reaction barrier $\left(8 \mathrm{kcal} / \mathrm{mol}\right.$ in our previous calculation $\left.{ }^{19}\right)$. These radicals may be distinguished in the infrared spectrum study due to the difference in the vibrational spectrum peaks for 2500 $\sim 3200 \mathrm{~cm}^{-1}$ (see Fig. S2 of the supporting information). The figure indicates that the reaction barrier energies $(52 \sim 62 \mathrm{kcal} / \mathrm{mol})$ are close to the dissociation energies, which are 


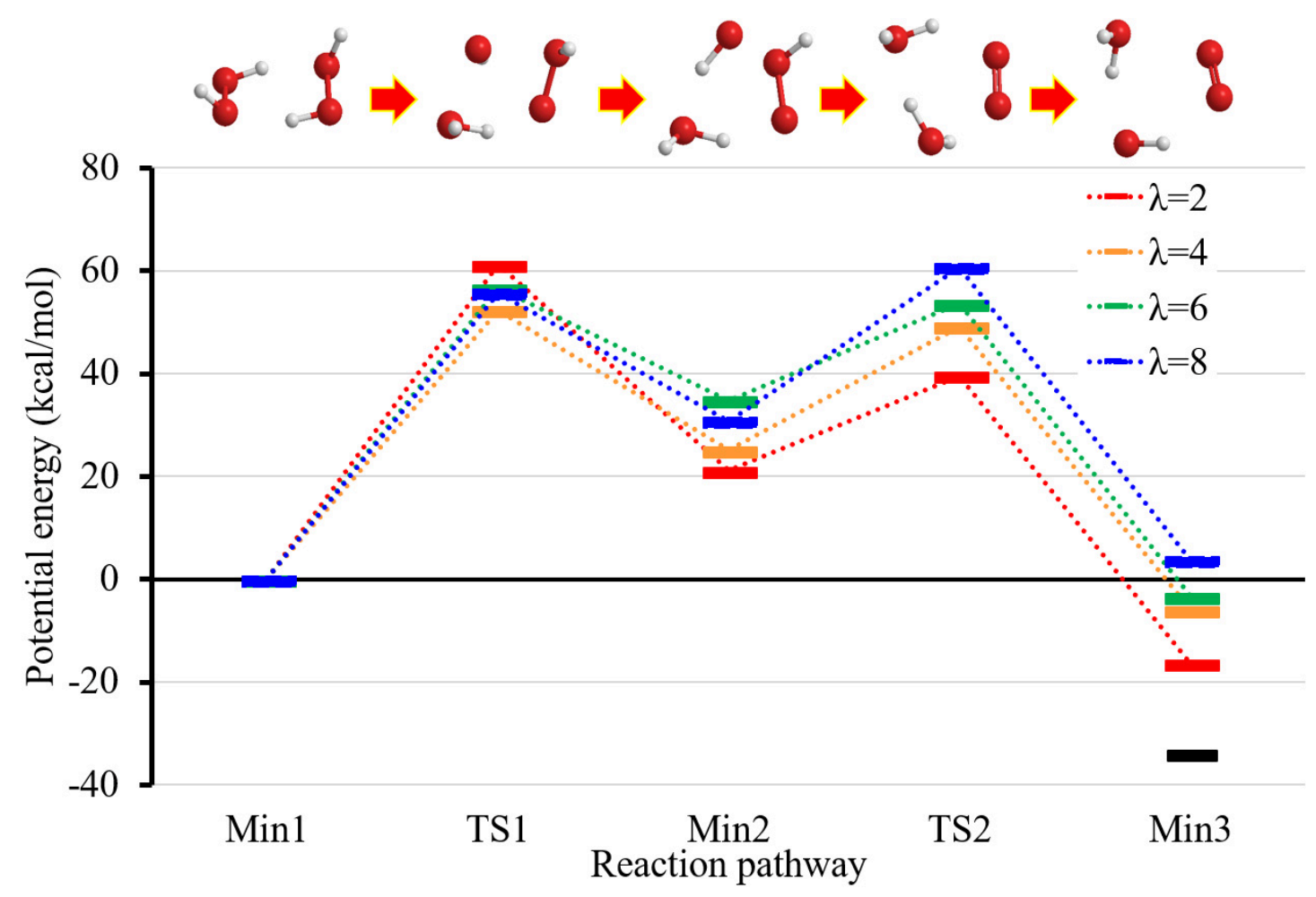

FIG. 3: Reaction diagram of $\mathrm{H}_{2} \mathrm{O}_{2}$ decomposition reaction, i.e., $2 \mathrm{H}_{2} \mathrm{O}_{2} \rightarrow \mathrm{O}_{2}+2 \mathrm{H}_{2} \mathrm{O}$, under the absence of metal ions in aqueous solution. LC-BLYP/cc-pVDZ is used with the solvent effect of the polarizable continuum model of water. Zero-point vibrational corrections are included. The molecular structures of the reaction processes are also shown for the complex with no water molecule. For Min3, the potential energy of the triplet state for $\lambda=8$ is also shown as a black bar.

shown in Fig. 2, and are much smaller than the dissociation barrier heights of the $\mathrm{H}_{2} \mathrm{O}_{2} \rightarrow$ $2 \mathrm{OH}$ reaction in aqueous solution mentioned above. The barrier energies tend to increase as the hydration number increases except for $\lambda=2$ of Min1, while the intermediate (Min2) and final (Min3) products are destabilized as the hydration number increases except for $\lambda=8$ of Min2. This is because both TSs and products contain neutral radicals such as $\mathrm{OOH}$ and $\mathrm{O}_{2}$, which are unstable in aqueous solution. It may be questionable that this reaction pathway provides only the singlet state energies, though $\mathrm{O}_{2}$ molecule has the ground triplet state. However, we consider that the real decomposition reaction also proceeds only through the singlet states. This is because the spin-forbidden spin-orbit transition probabilities from the singlet to triplet states are usually very small for such light and low-spin systems. The figure also shows that the $\mathrm{H}_{2} \mathrm{O}_{2}$ decomposition reaction is evaluated to be endothermic for 
$\lambda=8$. This result is also related to the spin-forbidden transitions, because $\mathrm{O}_{2}$ molecule is finally produced to be the ground triplet state. The triplet state energy of Min3 is shown for $\lambda=8$ as a black bar in Fig. 3. As clearly shown in the figure, this reaction is exothermic for the production of the triplet $\mathrm{O}_{2}$ molecules even for $\lambda=8$. We would emphasize that the above results are consistent with the experimental observations showing that $\mathrm{H}_{2} \mathrm{O}_{2}$ is hardly decomposed without metal ions in aqueous solution. Therefore, we conclude that $\mathrm{H}_{2} \mathrm{O}_{2}$ is decomposed by this mechanism under the absence of metal ions in aqueous solution.

\section{B. FeO hydration complex formation mechanism}

Next, we address the $\mathrm{H}_{2} \mathrm{O}_{2}$ decomposition mechanism under the presence of iron ions in aqueous solution. For exploring the decomposition mechanism, it is interesting to focus on the formation of the iron oxide ( $\mathrm{FeO})$ hydration complex. Baerends and coworkers explained that the $\mathrm{Fe}^{\mathrm{IV}} \mathrm{O}$ hydration complex is formed in the following two steps: ${ }^{9}$

1. The $\mathrm{O}-\mathrm{O}$ bond dissociation of $\mathrm{H}_{2} \mathrm{O}_{2}$ coordinating to the ferrous ion hydration complex proceeds to form $\mathrm{OH}$ radicals coordinating to the tetravalent iron ion hydration complex: i.e.,

$$
\left[\mathrm{Fe}^{\mathrm{II}}\left(\mathrm{H}_{2} \mathrm{O}_{2}\right)\left(\mathrm{H}_{2} \mathrm{O}\right)_{5}\right]^{2+} \rightarrow\left[\mathrm{Fe}^{\mathrm{IV}}(\mathrm{OH})_{2}\left(\mathrm{H}_{2} \mathrm{O}\right)_{4}\right]^{2+}+\mathrm{H}_{2} \mathrm{O}
$$

and

2. the FeO hydration complex is then formed from the $\mathrm{OH}$ radicals coordinating to the tetravalent iron ion hydration complex: i.e.,

$$
\left[\mathrm{Fe}^{\mathrm{IV}}(\mathrm{OH})_{2}\left(\mathrm{H}_{2} \mathrm{O}\right)_{4}\right]^{2+} \rightarrow\left[\mathrm{Fe}^{\mathrm{IV}} \mathrm{O}\left(\mathrm{H}_{2} \mathrm{O}\right)_{5}\right]^{2+}
$$

They suggested that steps 1 and 2 require very low barriers with only 6 and $2 \mathrm{kcal} / \mathrm{mol}$, respectively, both of which are too low to inhibit the $\mathrm{H}_{2} \mathrm{O}_{2}$ decomposition proceeding at room temperature. We first explored the FeO formation mechanism on the basis of this study.

As a result, we found that the FeO hydration complex is formed in one step and that this step requires much higher reaction barriers for the ferrous ion hydration complex. Figure 4 displays the calculated potential energy curves of the O-O bond dissociation for two types 


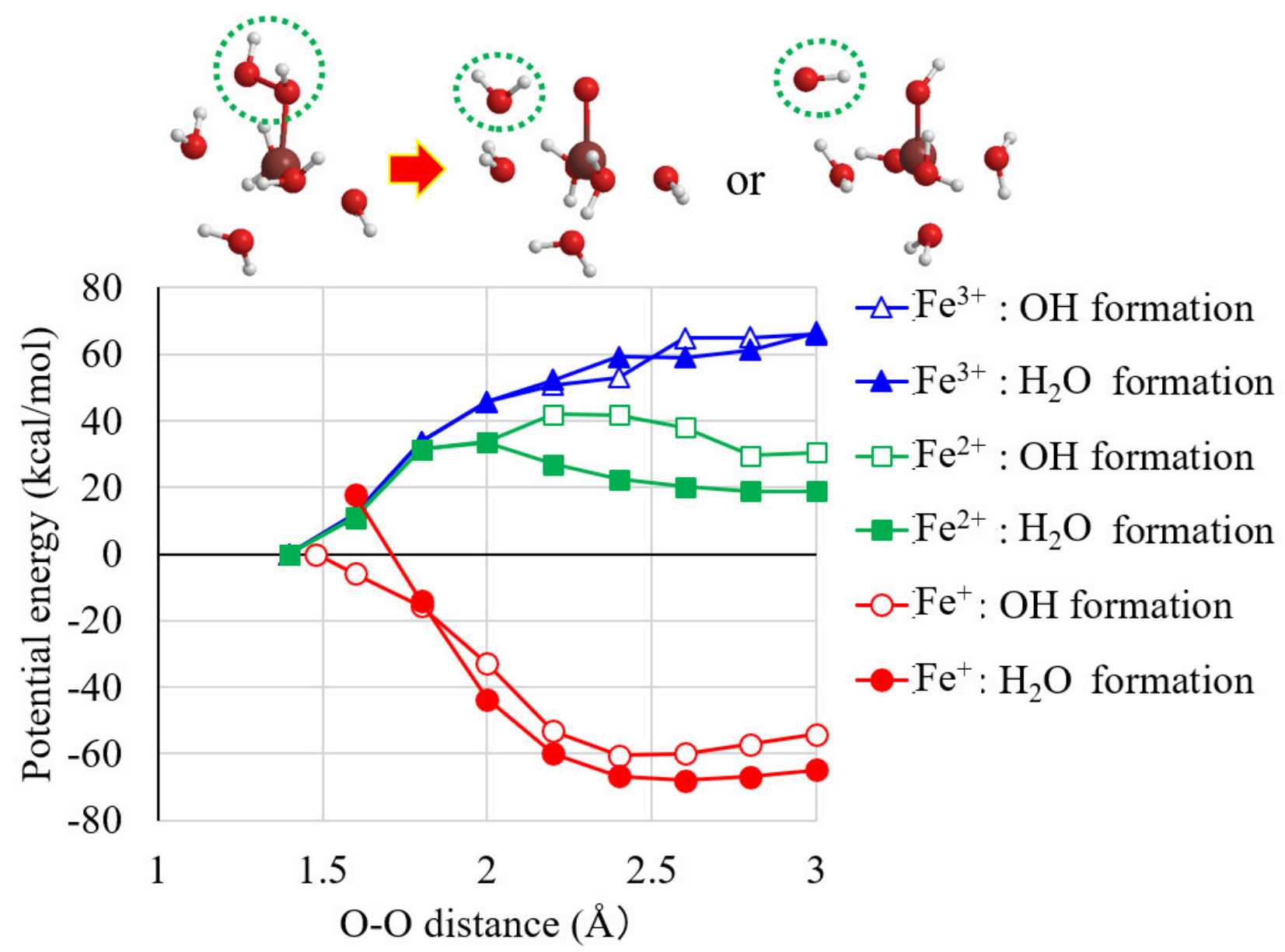

FIG. 4: Potential energy curves of the $\mathrm{O}-\mathrm{O}$ bond dissociation of $\mathrm{H}_{2} \mathrm{O}_{2}$, which is coordinated to the iron ion hydration complexes in $\left[\mathrm{Fe}\left(\mathrm{H}_{2} \mathrm{O}_{2}\right)\left(\mathrm{H}_{2} \mathrm{O}\right)_{5}\right]^{n+}$, for the valence of $n=1,2$, and 3. LCBLYP/cc-pVDZ/LanL2DZ is used with the solvent effect of the polarizable continuum model of water. The dotted green circles indicate the $\mathrm{H}_{2} \mathrm{O}_{2}$ molecule and formed $\mathrm{H}_{2} \mathrm{O}$ molecule and $\mathrm{OH}$ radical.

of the $\mathrm{O}-\mathrm{O}$ dissociations: $\mathrm{OH}$ and $\mathrm{H}_{2} \mathrm{O}$ formations. The $\mathrm{OH}$ formation type of the reaction corresponds to the above-mentioned first step: i.e.,

$$
\left[\mathrm{Fe}\left(\mathrm{H}_{2} \mathrm{O}_{2}\right)\left(\mathrm{H}_{2} \mathrm{O}\right)_{5}\right]^{n+} \rightarrow\left[\mathrm{Fe}(\mathrm{OH})_{2}\left(\mathrm{H}_{2} \mathrm{O}\right)_{4}\right]^{n+}+\mathrm{H}_{2} \mathrm{O}
$$

On the other hand, the $\mathrm{H}_{2} \mathrm{O}$ formation type corresponds to the integration of the first and second processes: i.e.,

$$
\left[\mathrm{Fe}\left(\mathrm{H}_{2} \mathrm{O}_{2}\right)\left(\mathrm{H}_{2} \mathrm{O}\right)_{5}\right]^{n+} \rightarrow\left[\mathrm{FeO}\left(\mathrm{H}_{2} \mathrm{O}\right)_{5}\right]^{n+}+\mathrm{H}_{2} \mathrm{O}
$$


As the figure clearly shows, for the ferrous $\left(\mathrm{Fe}^{2+}\right)$ ion hydration complex, the $\mathrm{H}_{2} \mathrm{O}$ formation type gives a high reaction barrier $(\sim 34 \mathrm{kcal} / \mathrm{mol})$, while the $\mathrm{OH}$ formation type provides a higher barrier height ( $\sim 40 \mathrm{kcal} / \mathrm{mol})$. This is obviously inconsistent with the experimental results showing that $\mathrm{O}_{2}$ is rapidly produced in $\mathrm{H}_{2} \mathrm{O}_{2}$ solution under the presence of ferrous ions. We also examined ferric $\left(\mathrm{Fe}^{3+}\right)$ ion hydration complex, because this ion is also experimentally detected ${ }^{10}$ and there is an experiment measuring the decomposition rate. ${ }^{39}$ As a result, we found that the barrier heights increase to more than $65 \mathrm{kcal} / \mathrm{mol}$, which are higher than the barrier heights of the $\mathrm{O}-\mathrm{O}$ dissociation of $\mathrm{H}_{2} \mathrm{O}_{2}$ without metal ions in Fig. 2. These results indicate that the FeO complex is rapidly formed by neither ferrous nor ferric ion hydration complexes at room temperature.

Monovalent iron ion hydration complex, i.e., $\left[\mathrm{Fe}\left(\mathrm{H}_{2} \mathrm{O}_{2}\right)\left(\mathrm{H}_{2} \mathrm{O}\right)_{5}\right]^{+}$, is, therefore, examined as a $\mathrm{FeO}$ formation species. As far as we know, this complex has never been assumed to be a decomposition catalyst, because monovalent iron $\left(\mathrm{Fe}^{+}\right)$ion is essentially unstable. Note that we assume not the production of $\mathrm{Fe}^{+}$ions but the electron transfer to the ligand molecules of the $\mathrm{H}_{2} \mathrm{O}_{2}$-coordinated ferrous ion hydration complex. This assumption is supported by an experimental evidence that the ferrous ion chelate complex with an electron-donating citrate acid is much more susceptible to oxidation than $\left[\mathrm{Fe}\left(\mathrm{H}_{2} \mathrm{O}\right)_{6}\right]^{2+}$ complex. ${ }^{40,41}$ The production of ferric ions also implicitly supports this assumption, because an electron must be generated to produce ferric ions from ferrous ions: i.e.,

$$
2\left[\mathrm{Fe}\left(\mathrm{H}_{2} \mathrm{O}\right)_{6}\right]^{2+} \rightarrow\left[\mathrm{Fe}\left(\mathrm{H}_{2} \mathrm{O}\right)_{6}\right]^{3+}+\left[\mathrm{Fe}\left(\mathrm{H}_{2} \mathrm{O}\right)_{6}\right]^{+}
$$

Figure 4 shows that the $\mathrm{OH}$ formation type provides no barrier for the monovalent iron ion hydration complex. This indicates that $\mathrm{H}_{2} \mathrm{O}_{2}$ is rapidly decomposed into $\mathrm{OH}$ radicals after the electron transfer to the ferrous ion hydration complex, as seen in the experiments. This result strongly suggests that the electron transfer to $\mathrm{H}_{2} \mathrm{O}_{2}$ coordinating to the ferrous ion complex is a precursory process of the $\mathrm{H}_{2} \mathrm{O}_{2}$ decomposition.

Figure 4 also indicates that $\mathrm{H}_{2} \mathrm{O}$ formation provides higher barrier for the short $\mathrm{O}-\mathrm{O}$ distance, though it gives a more stable potential energy. Considering that the $\mathrm{OH}$ radical from the dissociated $\mathrm{H}_{2} \mathrm{O}_{2}$ would form $\mathrm{H}_{2} \mathrm{O}$ through the hydrogen bond network, we arranged two $\mathrm{H}_{2} \mathrm{O}$ molecules around $\mathrm{H}_{2} \mathrm{O}_{2}$ to maximize the number of hydrogen bonds and optimized the geometry of the complex. We, consequently, found that the dissociated $\mathrm{OH}$ radical forms $\mathrm{H}_{2} \mathrm{O}$ with no reaction barrier to produce the $\mathrm{Fe}(\mathrm{OH})_{2}$ hydration complex in a similar way 
to the first reaction process of Baerends et al. ${ }^{9}$ in Eq. (17), i.e.,

$$
\left[\mathrm{Fe}^{\mathrm{I}}\left(\mathrm{H}_{2} \mathrm{O}_{2}\right)\left(\mathrm{H}_{2} \mathrm{O}\right)_{5}\right]^{+} \rightarrow\left[\mathrm{Fe}^{\mathrm{III}}(\mathrm{OH})_{2}\left(\mathrm{H}_{2} \mathrm{O}\right)_{4}\right]^{+}+\mathrm{H}_{2} \mathrm{O}
$$

As mentioned in Sec. III C, we found that the subsequent $\mathrm{FeO}^{+}$hydration complex formation from the $\left[\mathrm{Fe}(\mathrm{OH})_{2}\right]^{+}$hydration complex, i.e.,

$$
\left[\mathrm{Fe}^{\mathrm{II}}(\mathrm{OH})_{2}\left(\mathrm{H}_{2} \mathrm{O}\right)_{4}\right]^{+} \rightarrow\left[\mathrm{Fe}^{\mathrm{II}} \mathrm{O}\left(\mathrm{H}_{2} \mathrm{O}\right)_{5}\right]^{+}
$$

requires the reaction barrier of $16.5 \mathrm{kcal} / \mathrm{mol}$, which is considered to proceed at room temperature, when $\mathrm{H}_{2} \mathrm{O}_{2}$ is coordinated to the complex. We, therefore, conclude that the $\mathrm{Fe}(\mathrm{OH})_{2}^{+}$ hydration complex is first produced from the $\mathrm{O}-\mathrm{O}$ dissociation of $\mathrm{H}_{2} \mathrm{O}_{2}$, and then, the $\mathrm{FeO}^{+}$ hydration complex is formed by the transformation of the $\mathrm{Fe}(\mathrm{OH})_{2}^{+}$complex, and finally, $\mathrm{FeO}^{2+}$ hydration complex is produced by losing an electron.

How are the monovalent iron ion hydration complex produced in the solution of the ferrous ion hydration complex? For iron ions in aqueous solution, Marcus exemplified a ferrous-ferric exchange reaction,

$$
\mathrm{Fe}^{2+}(\mathrm{aq})+\mathrm{Fe}^{3+}(\mathrm{aq}) \rightleftharpoons \mathrm{Fe}^{3+}(\mathrm{aq})+\mathrm{Fe}^{2+}(\mathrm{aq})
$$

as a typical electron transfer system in inorganic electrochemistry and developed a guiding theory for this exchange reaction. ${ }^{42}$ This exchange reaction is a rare event, because it needs $0.1 \mathrm{~s}$ to proceed at equilibrium. ${ }^{43}$ Note, however, that in chemical kinetics, this small reaction rate comes from the identity of the reactant and product. The present reaction is considered to proceed by the disproportion reaction of the ferrous ion hydration complex, i.e.,

$$
2\left[\mathrm{Fe}^{\mathrm{II}}\left(\mathrm{H}_{2} \mathrm{O}\right)_{6}\right]^{2+} \rightleftharpoons\left[\mathrm{Fe}^{\mathrm{III}}\left(\mathrm{H}_{2} \mathrm{O}\right)_{6}\right]^{3+}+\left[\mathrm{Fe}^{\mathrm{I}}\left(\mathrm{H}_{2} \mathrm{O}\right)_{6}\right]^{+} .
$$

and then, the monovalent iron complex is rapidly oxidized to FeO hydration complex, i.e.,

$$
\left[\mathrm{Fe}^{\mathrm{I}}\left(\mathrm{H}_{2} \mathrm{O}_{2}\right)\left(\mathrm{H}_{2} \mathrm{O}\right)_{5}\right]^{+} \rightleftharpoons\left[\mathrm{Fe}^{\mathrm{II}} \mathrm{O}\left(\mathrm{H}_{2} \mathrm{O}\right)_{5}\right]^{+}+\mathrm{H}_{2} \mathrm{O} \text {. }
$$

This reaction is considered to mainly proceed when $\mathrm{H}_{2} \mathrm{O}_{2}$ is coordinated to the ferrous ion hydration complex, because the monovalent ion complex is essentially less stable than the ferrous and ferric ion complexes: i.e., for Eq. (25),

$$
\left[\mathrm{Fe}^{\mathrm{II}}\left(\mathrm{H}_{2} \mathrm{O}\right)_{6}\right]^{2+}+\left[\mathrm{Fe}^{\mathrm{II}}\left(\mathrm{H}_{2} \mathrm{O}_{2}\right)\left(\mathrm{H}_{2} \mathrm{O}\right)_{5}\right]^{2+} \rightleftharpoons\left[\mathrm{Fe}^{\mathrm{II}}\left(\mathrm{H}_{2} \mathrm{O}\right)_{6}\right]^{3+}+\left[\mathrm{Fe}^{\mathrm{I}}\left(\mathrm{H}_{2} \mathrm{O}_{2}\right)\left(\mathrm{H}_{2} \mathrm{O}\right)_{5}\right]^{+} .
$$




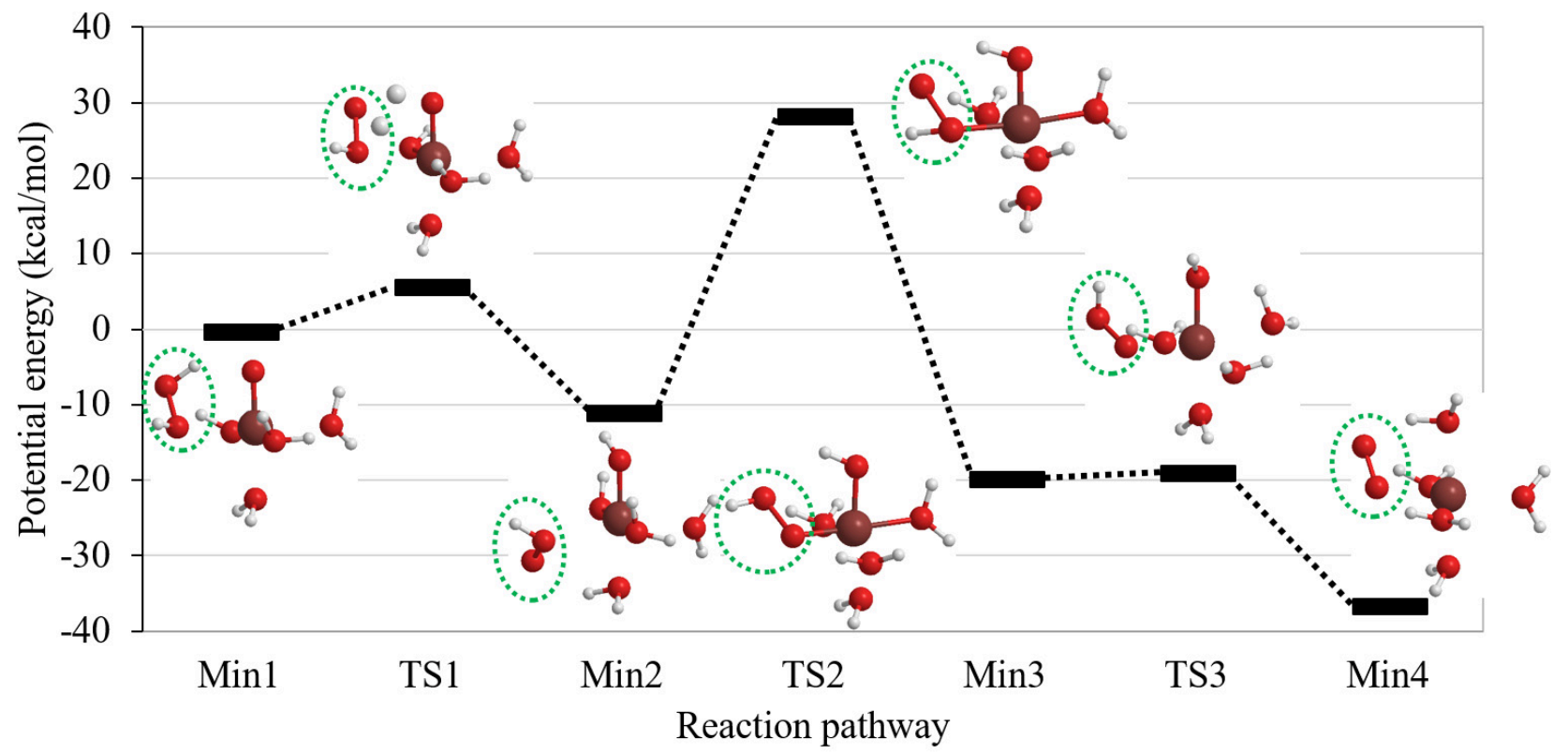

FIG. 5: $\mathrm{O}_{2}$ formation mechanism of the $\mathrm{H}_{2} \mathrm{O}_{2}$-coordinated $\mathrm{FeO}^{+}$ion hydration complex with no additional $\mathrm{H}_{2} \mathrm{O}$ molecules, i.e., $\left[\mathrm{FeO}\left(\mathrm{H}_{2} \mathrm{O}_{2}\right)\left(\mathrm{H}_{2} \mathrm{O}\right)_{4}\right]^{+}$. LC-BLYP/cc-pVDZ/LanL2DZ is used with the solvent effect of the polarizable continuum model of water. Zero-point vibrational corrections are included. The potential energy of the reactant complex (Min1) is set to be zero. The dotted green circles indicate the $\mathrm{H}_{2} \mathrm{O}_{2}$ molecules and their decomposed fragments.

Since the concentration of the monovalent ion complex is reduced as a consequence of Eq. (26), the disproportion reaction in Eq. (25) kinetically proceeds rightward. This is contrasting to the identical reaction in Eq. (24), which is considered to be driven by environmental fluctuations from an energetical viewpoint. ${ }^{43}$ In addition, the products of these reactions, $\mathrm{FeO}$ and $\mathrm{Fe}^{3+}$ hydration complexes, are consistent with the experimental result, ${ }^{10}$ as mentioned in Sec. I.

\section{C. $\mathrm{O}_{2}$ formation mechanism from $\mathrm{H}_{2} \mathrm{O}_{2}$-coordinated $\mathrm{FeO}$ hydration complex}

Following the very low reaction barrier of the $\mathrm{FeO}^{+}$hydration complex formation, it is meaningful to explore the subsequent $\mathrm{O}_{2}$ formation mechanism from the monovalent iron ion hydration complex. We first examined the $\mathrm{O}_{2}$ formation mechanism from the hydration complex with no additional hydration water molecule, i.e., $\left[\mathrm{FeO}\left(\mathrm{H}_{2} \mathrm{O}_{2}\right)\left(\mathrm{H}_{2} \mathrm{O}\right)_{4}\right]^{+}$. Figure 5 illustrates the calculated reaction energy diagram of the $\mathrm{O}_{2}$ formation mechanism. As shown 
in the figure, a high barrier $(39.3 \mathrm{kcal} / \mathrm{mol})$ is given for the hydrogen transfer between the oxygen atoms of $\mathrm{H}_{2} \mathrm{O}_{2}$ in the second process (Min2 $\rightarrow$ Min3):

$$
\left[\mathrm{Fe}(\mathrm{OH})(\mathrm{OHO})\left(\mathrm{H}_{2} \mathrm{O}\right)_{4}\right]^{+} \rightarrow\left[\mathrm{Fe}(\mathrm{OH})(\mathrm{OOH})\left(\mathrm{H}_{2} \mathrm{O}\right)_{4}\right]^{+}
$$

while low barriers are provided for the first and third processes: 9.2 and $4.0 \mathrm{kcal} / \mathrm{mol}$, respectively. Though this barrier is lower than those of the decomposition without metal ions $(52 \sim 62 \mathrm{kcal} / \mathrm{mol})$, it is too high to be consistent with the experimental results showing the rapid $\mathrm{O}_{2}$ formation at room temperature. We considered that this high barrier comes from the neglect of the hydrogen bond network around $\mathrm{H}_{2} \mathrm{O}_{2}$, because hydrogen transfers frequently occur in the hydrogen bond networks.

We have, therefore, added two hydration water molecules to the $\mathrm{FeO}^{+}$hydration complex, i.e.,

$$
\left[\mathrm{FeO}\left(\mathrm{H}_{2} \mathrm{O}_{2}\right)\left(\mathrm{H}_{2} \mathrm{O}\right)_{6}\right]^{+} \rightarrow\left[\mathrm{Fe}(\mathrm{OH})_{2}\left(\mathrm{H}_{2} \mathrm{O}_{2}\right)\left(\mathrm{H}_{2} \mathrm{O}\right)_{5}\right]^{+} \rightarrow\left[\mathrm{Fe}\left(\mathrm{H}_{2} \mathrm{O}\right)_{7} \mathrm{O}_{2}\right]^{+}
$$

in order to model the hydrogen bond network between the coordinated $\mathrm{H}_{2} \mathrm{O}_{2}$ and surrounding $\mathrm{H}_{2} \mathrm{O}$ molecules. Figure 6 illustrates the reaction energy diagram of the $\mathrm{O}_{2}$ formation. As shown in the figure, the highest barrier is given for the first step (Min1 $\rightarrow$ Min2) as 14.0 $\mathrm{kcal} / \mathrm{mol}$, which is much lower than the barrier of the complex with no additional water molecule $(39.3 \mathrm{kcal} / \mathrm{mol})$. This low barrier is consistent with the experimentally-observed rapid $\mathrm{H}_{2} \mathrm{O}_{2}$ decomposition reaction under the presence of iron ions. This indicates that the hydrogen bond network around $\mathrm{H}_{2} \mathrm{O}_{2}$ significantly contributes to the $\mathrm{H}_{2} \mathrm{O}_{2}$ decomposition. Actually, the reaction energy diagram shows that hydrogen transfers mostly proceed through the hydrogen bond network. Note that the produced $\mathrm{O}_{2}$ in this mechanism (Min6) is also considered to have the singlet state, similar to that in the decomposition mechanism without metal ions in Fig. 2. We, therefore, optimized the sextet state of Min6, which must contain the triplet state of $\mathrm{O}_{2}$, and found that it becomes $-18.8 \mathrm{kcal} / \mathrm{mol}$ more stable than the quartet state of Min6, which must contain the singlet state of $\mathrm{O}_{2}$. As discussed in Sec. III A, we, however, consider that the decomposition reaction proceeds only through the singlet states due to the small spin-orbit transition probabilities. We would emphasize that this mechanism is clearly consistent with the recent experimental result, ${ }^{10}$ in which $\mathrm{OH}$ radicals hardly contribute to the $\mathrm{O}_{2}$ formation reaction, $\mathrm{FeO}$ and $\mathrm{Fe}^{3+}$ are produced from the $\mathrm{Fe}^{2+}$ hydration complex, and $\mathrm{H}_{2} \mathrm{O}_{2}$ is first replaced with a coordinated $\mathrm{H}_{2} \mathrm{O}$. We, therefore, 


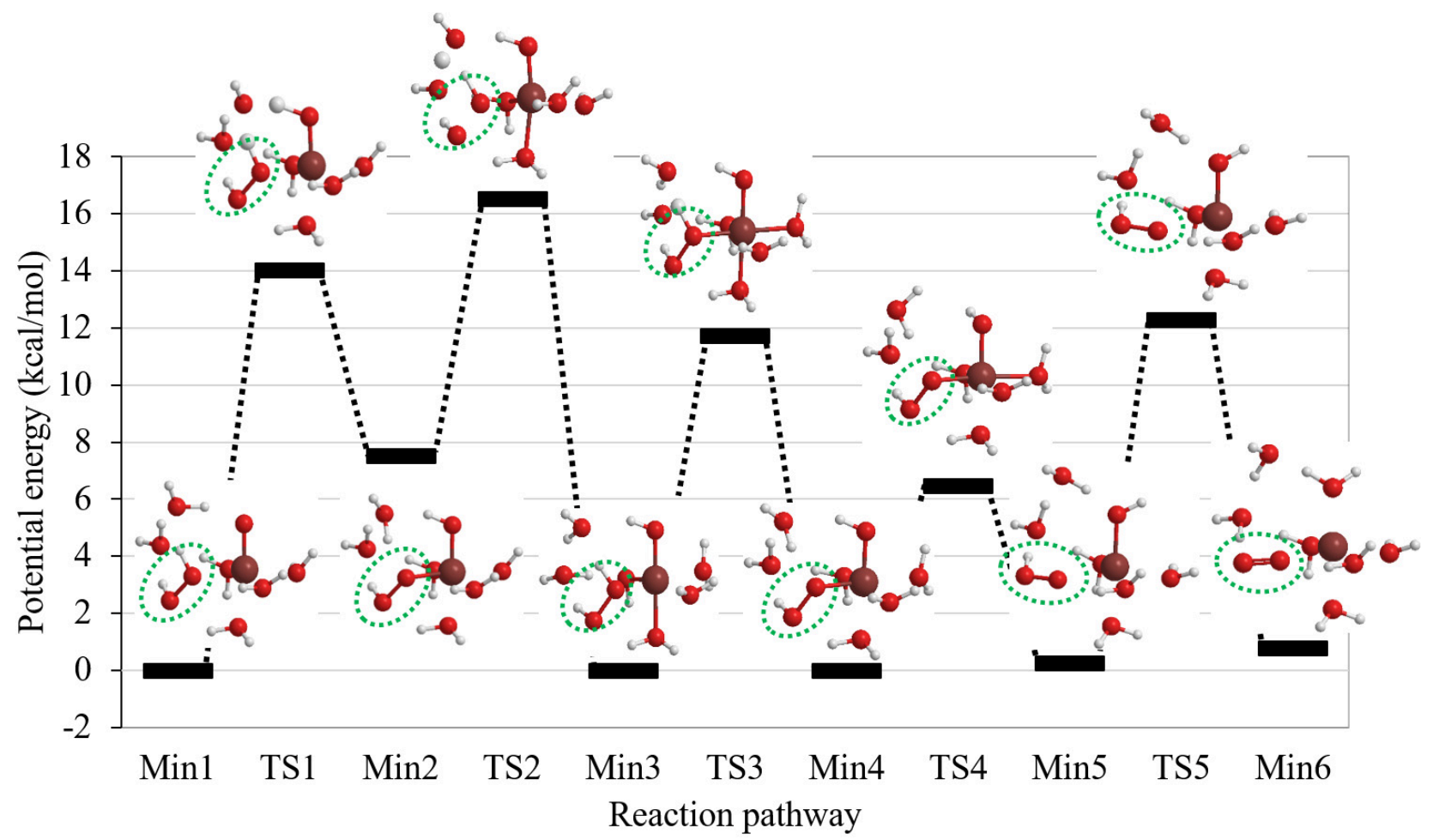

FIG. 6: $\mathrm{O}_{2}$ formation mechanism of the $\mathrm{H}_{2} \mathrm{O}_{2}$-coordinated $\mathrm{FeO}^{+}$ion hydration complex with two $\mathrm{H}_{2} \mathrm{O}$ molecules, i.e., $\left[\mathrm{FeO}\left(\mathrm{H}_{2} \mathrm{O}_{2}\right)\left(\mathrm{H}_{2} \mathrm{O}\right)_{4}\right]^{+}\left(\mathrm{H}_{2} \mathrm{O}\right)_{2}$. LC-BLYP/cc-pVDZ/LanL2DZ is used with the solvent effect of the polarizable continuum model of water. Zero-point vibrational corrections are included. The potential energy of the reactant complex (Min1) is set to be zero. The dotted green circles indicate the $\mathrm{H}_{2} \mathrm{O}_{2}$ molecules and their decomposed fragments.

conclude that the conventional $\mathrm{H}_{2} \mathrm{O}_{2}$ decomposition mechanism, which usually contain the $\mathrm{OH}$ radical production, should be replaced with this new mechanism.

Finally, it is interesting to note that Fig. 5 also reveals the $\mathrm{O}_{2}$ formation mechanism from the $\left[\mathrm{Fe}(\mathrm{OH})_{2}\right]^{+}$complex, which is obtained as a product in Eq. (22). Since Min3 in Fig. 5 corresponds to the $\left[\mathrm{Fe}(\mathrm{OH})_{2}\right]^{+}$complex coordinating $\mathrm{H}_{2} \mathrm{O}_{2}$, the $\mathrm{O}_{2}$ formation reaction from this complex is considered to take a short cut from this Min3. This result strongly suggests that the reaction proceeds directly from the $\left[\mathrm{Fe}(\mathrm{OH})_{2}\right]^{+}$complex bypassing the $\mathrm{FeO}^{+}$complex formation, i.e.,

$$
\left[\mathrm{Fe}^{\mathrm{III}}(\mathrm{OH})_{2}\left(\mathrm{H}_{2} \mathrm{O}\right)_{4}\right]^{+} \rightarrow\left[\mathrm{Fe}^{\mathrm{I}}\left(\mathrm{H}_{2} \mathrm{O}\right)_{6}\right]^{+}+\mathrm{O}_{2}
$$

This figure also indicates that the $\mathrm{FeO}^{+}$hydration complex is formed from the $\left[\mathrm{Fe}(\mathrm{OH})_{2}\right]^{+}$ complex with the reaction barrier of $16.5 \mathrm{kcal} / \mathrm{mol}$ in the backward process from Min3 
through Min1, while this barrier is small enough to initiate the reaction at room temperature as mentioned in Sec. III B. We, therefore, propose that this $\mathrm{H}_{2} \mathrm{O}_{2}$ decomposition mainly proceeds through the $\left[\mathrm{Fe}(\mathrm{OH})_{2}\right]^{+}$complex with forming the $\mathrm{FeO}^{+}$hydration complex as a by-product, though the decomposition reaction may also partly proceed from this $\mathrm{FeO}^{+}$ complex.

\section{CONCLUSIONS}

In this study, we have theoretically explored the $\mathrm{H}_{2} \mathrm{O}_{2}$ decomposition mechanisms under the absence and presence of Fe ions in aqueous solution, following recent experimental studies on this topic. We have consequently revealed the $\mathrm{H}_{2} \mathrm{O}_{2}$ decomposition mechanisms, which contain no $\mathrm{OH}$ radical formations as supported by the experimental results.

We first addressed the $\mathrm{H}_{2} \mathrm{O}_{2}$ decomposition under the absence of metal ions in aqueous solution. As a test, we calculated the $\mathrm{O}-\mathrm{O}$ dissociation potential energy curves of $\mathrm{H}_{2} \mathrm{O}_{2}$ with several numbers of explicitly-hydrated water molecules in the solvent model of water, under the spin-stability conditions for switching the spin-restricted and -unrestricted Kohn-Sham calculations. The calculated results show that although the O-O dissociation potentials asymptotically approach the energies of $\mathrm{OH}$ radicals, they essentially require the spin-forbidden transitions. We, therefore, presumed an $\mathrm{H}_{2} \mathrm{O}_{2}$ decomposition mechanism using $\mathrm{H}_{2} \mathrm{O}_{2}$ dimer and calculated the reaction energy diagrams for several hydration numbers. As a result, we found that this mechanism provides reasonable barrier heights (52 $\sim 62 \mathrm{kcal} / \mathrm{mol}$ ), which are close to the experimentally-evaluated activation energy (47.8 $\mathrm{kcal} / \mathrm{mol}$ ). We, therefore, conclude that this is the $\mathrm{H}_{2} \mathrm{O}_{2}$ decomposition mechanism under the absence of metal ions.

Next, we explored the $\mathrm{H}_{2} \mathrm{O}_{2}$ decomposition under the presence of Fe ions in aqueous solution. Following a recent experimental study, ${ }^{10}$ we calculated the O-O dissociation potential energy curves of $\mathrm{H}_{2} \mathrm{O}_{2}$ coordinating to the Fe ion hydration complex to produce the $\mathrm{FeO}$ hydration complex. As a result, we surprisingly found that the monovalent Fe ion hydration complex, $\left[\mathrm{Fe}\left(\mathrm{H}_{2} \mathrm{O}_{2}\right)\left(\mathrm{H}_{2} \mathrm{O}\right)_{5}\right]^{+}$, has no reaction barrier for the dissociation of $\mathrm{H}_{2} \mathrm{O}_{2}$, while the ferrous $\left(\mathrm{Fe}^{2+}\right)$ and ferric $\left(\mathrm{Fe}^{3+}\right)$ ion hydration complexes have very high reaction barriers. We also found that the Fe hydroxide $\mathrm{Fe}(\mathrm{OH})_{2}^{+}$ion hydration complex is first produced, and then, it is transformed into the $\mathrm{FeO}^{+}$ion hydration complex. We have turned up several 


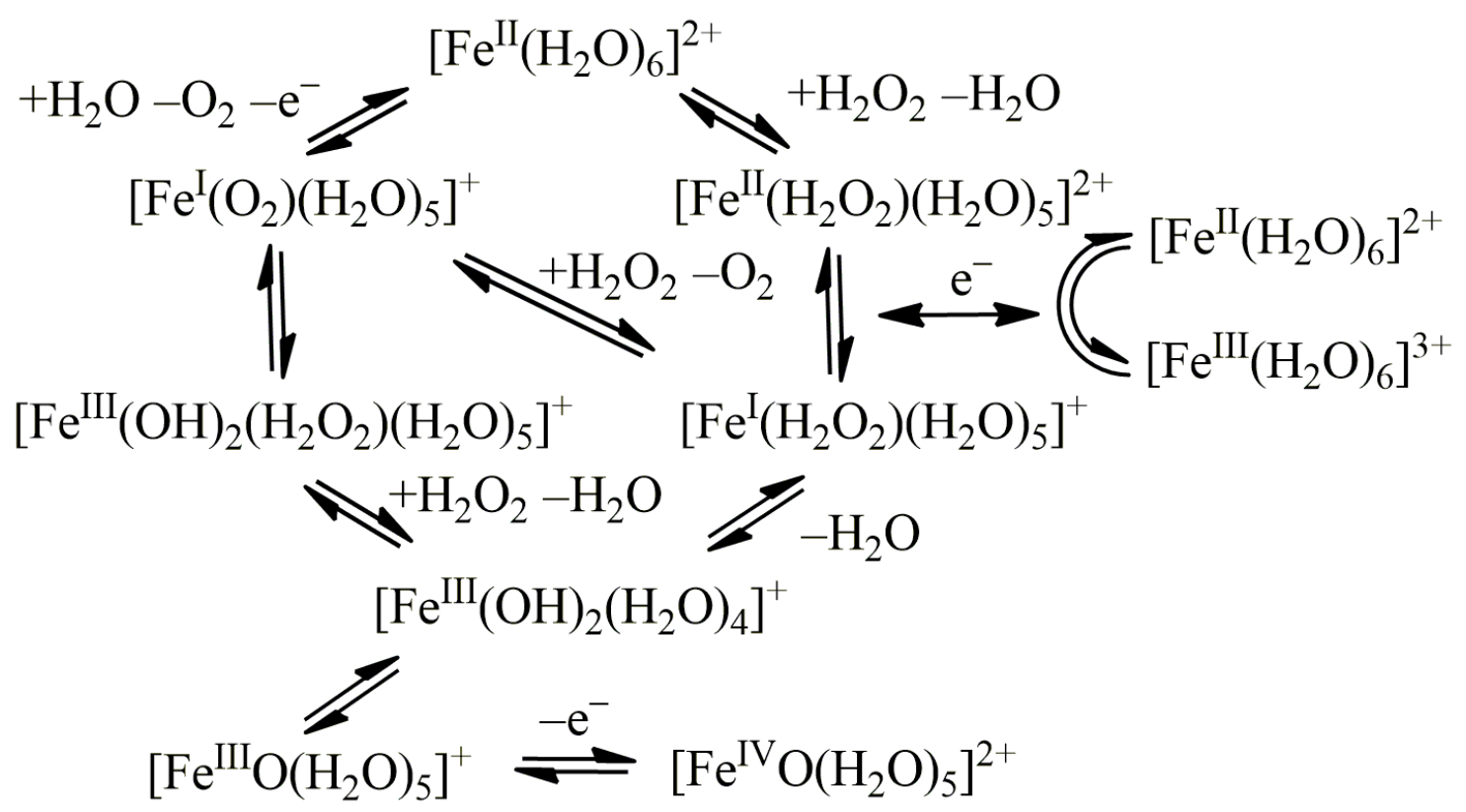

FIG. 7: Schematic overview of $\mathrm{H}_{2} \mathrm{O}_{2}$ decomposition mechanism by iron ion hydration complex.

experimental evidences supporting this finding and have theoretically discussed its validity.

Based on this result, we investigated the subsequent $\mathrm{O}_{2}$ formation mechanism after the $\mathrm{FeO}^{+}$hydration complex formation. We calculated the reaction energy diagram of this formation reaction for the $\mathrm{FeO}^{+}$complex with no hydrogen bond network around the coordinating $\mathrm{H}_{2} \mathrm{O}_{2}$ molecule. The calculated diagram shows that this reaction provides a high barrier $(39.3 \mathrm{kcal} / \mathrm{mol})$ for the hydrogen transfer between the oxygen atoms of $\mathrm{H}_{2} \mathrm{O}_{2}$. We, therefore, attached two hydration water molecules to $\mathrm{H}_{2} \mathrm{O}_{2}$ to model the hydrogen bond network. As a result, we found that the highest barrier height dramatically decreases to $14.0 \mathrm{kcal} / \mathrm{mol}$ indicating that this reaction proceeds even at room temperature as experimentally observed. We also found that the $\mathrm{O}_{2}$ formation reaction has a short cut from the $\mathrm{Fe}(\mathrm{OH})_{2}^{+}$complex and the FeO complex is considered to be a by-product of this reaction. The overall mechanism of the $\mathrm{H}_{2} \mathrm{O}_{2}$ decomposition reaction by Fe ion hydration complex is illustrated in Fig. 7. We, therefore, conclude that the $\mathrm{H}_{2} \mathrm{O}_{2}$ decomposition under the presence of Fe ions is driven by the electron transfer to the Fe ion hydration complex, and proceeds by the assistance of the hydrogen transfers in the hydrogen bond network around $\mathrm{H}_{2} \mathrm{O}_{2}$. This indicates that electron transfers from other complexes and hydrogen transfers through surrounding hydrogen bond network play a crucial role in the catalytic reactions of metal complexes. 


\section{ACKNOWLEDGMENTS}

This research was supported by the Superlative, Stable, and Scalable Performance Fuel Cell (SPer-FC) project of the New Energy and Industrial Technology Development Organization (NEDO) and by the Japanese Ministry of Education, Culture, Sports, Science and Technology (MEXT) (Grants: 17H01188 and 16KT0047). This study was also partly supported by MEXT as "Priority Issue on Post-K computer" (Development of new fundamental technologies for high-efficiency energy creation, conversion/storage and use).

\section{SUPPLEMENTARY MATERIAL AVAILABLE}

The molecular structures of $\mathrm{H}_{2} \mathrm{O}_{2}$ decomposition reaction at each step for the explicit hydration numbers of $\lambda=2,4,6$ and 8 have been provided in Fig. S1. The calculated vibrational spectra of $\mathrm{OHOHO}$ and $\mathrm{HOOOH}$ radicals, which are coordinated by two $\mathrm{H}_{2} \mathrm{O}$ molecules, have also been given in Fig. S2. This material is available free of charge via the Internet at $\mathrm{xxxx}$. 


\section{FIGURE CAPTIONS}

Fig. 1.

Calculation models of (a) hydrated $\mathrm{H}_{2} \mathrm{O}_{2}$ monomer with $\lambda$ hydration water molecules $\left(\left[\left(\mathrm{H}_{2} \mathrm{O}_{2}\right)_{2}\left(\mathrm{H}_{2} \mathrm{O}\right)_{\lambda}\right]\right)$, (b) hydrated $\mathrm{H}_{2} \mathrm{O}_{2}$ dimer with $\lambda$ hydration water molecules $\left(\left[\left(\mathrm{H}_{2} \mathrm{O}_{2}\right)_{2}\left(\mathrm{H}_{2} \mathrm{O}\right)_{\lambda}\right]\right)$, (c) iron ion $\left(\mathrm{Fe}^{n+}\right)$ hydration complexes with $\lambda$ coordinating water molecules $\left(\left[\mathrm{Fe}\left(\mathrm{H}_{2} \mathrm{O}_{2}\right)\left(\mathrm{H}_{2} \mathrm{O}\right)_{5}\right]^{n+}\right)$, and $(\mathrm{d})$ iron oxide ion $\left(\mathrm{FeO}^{n+}\right)$ hydration complexes with $\lambda$ coordinating water molecules and two additional water molecules $\left(\left[\mathrm{FeO}\left(\mathrm{H}_{2} \mathrm{O}_{2}\right)\left(\mathrm{H}_{2} \mathrm{O}\right)_{5}\right]^{n+}\left(\mathrm{H}_{2} \mathrm{O}\right)_{2}\right)$.

Fig. 2

Potential energy curves of the O-O dissociation of $\mathrm{H}_{2} \mathrm{O}_{2}$ to $\mathrm{OH}$ radicals for the explicit hydration numbers $\lambda=0,2,4,6$, and 8 in aqueous solution. The spin-restricted Kohn-Sham calculations are performed under the stability condition for switching to the spin-unrestricted ones. ${ }^{29,30}$ LC-BLYP/cc-pVDZ is used with the solvent effect of the polarizable continuum model of water. The minimum potential energies are set to be zero. The dissociation limit energies, which are calculated by equally dividing the hydrated $\mathrm{H}_{2} \mathrm{O}_{2}$ such as $\mathrm{H}_{2} \mathrm{O}_{2}\left(\mathrm{H}_{2} \mathrm{O}\right)_{2 \lambda}$ $\rightarrow 2 \mathrm{OH}\left(\mathrm{H}_{2} \mathrm{O}\right)_{\lambda}$, are also shown at the infinite O-O distance.

Fig. 3.

Reaction diagrams of $\mathrm{H}_{2} \mathrm{O}_{2}$ decomposition reaction, i.e., $2 \mathrm{H}_{2} \mathrm{O}_{2} \rightarrow \mathrm{O}_{2}+2 \mathrm{H}_{2} \mathrm{O}$, under the absence of metal ions in aqueous solution. LC-BLYP/cc-pVDZ is used with the solvent effect of the polarizable continuum model of water. Zero-point vibrational corrections are included. The molecular structures of the reaction processes are also shown for the complex with no water molecule. For Min3, the potential energy of the triplet state for $\lambda=8$ is also shown as a black bar.

Fig. 4.

Potential energy curves of the $\mathrm{O}-\mathrm{O}$ bond dissociation of $\mathrm{H}_{2} \mathrm{O}_{2}$, which is coordinated to the iron ion hydration complexes in $\left[\mathrm{Fe}\left(\mathrm{H}_{2} \mathrm{O}_{2}\right)\left(\mathrm{H}_{2} \mathrm{O}\right)_{5}\right]^{n+}$, for the valence of $n=1,2$, and 3 . LC-BLYP/cc-pVDZ/LanL2DZ is used with the solvent effect of the polarizable continuum model of water. The dotted green circles indicate the $\mathrm{H}_{2} \mathrm{O}_{2}$ molecule and formed $\mathrm{H}_{2} \mathrm{O}$ molecule and $\mathrm{OH}$ radical. 
Fig. 5.

$\mathrm{O}_{2}$ formation mechanism of the $\mathrm{H}_{2} \mathrm{O}_{2}$-coordinated $\mathrm{FeO}^{+}$ion hydration complex with no additional $\mathrm{H}_{2} \mathrm{O}$ molecules, i.e., $\left[\mathrm{FeO}\left(\mathrm{H}_{2} \mathrm{O}_{2}\right)\left(\mathrm{H}_{2} \mathrm{O}\right)_{4}\right]^{+}$. LC-BLYP/cc-pVDZ/LanL2DZ is used with the solvent effect of the polarizable continuum model of water. Zero-point vibrational corrections are included. The potential energy of the reactant complex (Min1) is set to be zero. The dotted green circles indicate the $\mathrm{H}_{2} \mathrm{O}_{2}$ molecules and their decomposed fragments.

Fig. 6.

$\mathrm{O}_{2}$ formation mechanism of the $\mathrm{H}_{2} \mathrm{O}_{2}$-coordinated $\mathrm{FeO}^{+}$ion hydration complex with two $\mathrm{H}_{2} \mathrm{O}$ molecules, i.e., $\left[\mathrm{FeO}\left(\mathrm{H}_{2} \mathrm{O}_{2}\right)\left(\mathrm{H}_{2} \mathrm{O}\right)_{4}\right]^{+}\left(\mathrm{H}_{2} \mathrm{O}\right)_{2}$. LC-BLYP/cc-pVDZ/LanL2DZ is used with the solvent effect of the polarizable continuum model of water. Zero-point vibrational corrections are included. The potential energy of the reactant complex (Min1) is set to be zero. The dotted green circles indicate the $\mathrm{H}_{2} \mathrm{O}_{2}$ molecules and their decomposed fragments.

Fig. 7.

Schematic overview of $\mathrm{H}_{2} \mathrm{O}_{2}$ decomposition mechanism by iron ion hydration complex. 
* Electronic address: ttsuneda@yamanashi.ac.jp

1 Bishop DF, Stern G, Fleischman M, Marshall LS. I\&EC Process Design and Development. $1968 ; 7: 110-117$.

2 Walling C, Goosen A. J Am Chem Soc. 1973;95:2987-2991.

3 Fenton HJH. J Chem Soc Trans. 1894;65:899-910.

4 Haber F, Weiss J. Proc R Soc London A. 1934;147:332-351.

5 Takagi J, Ishigure K. Nucl Sci Eng. 1985;89:177-186.

${ }^{6}$ Barb WG, Baxendale JH, George P, Hargrave KR. Reactions of ferrous and ferric ions with hydrogen peroxide. Part I. The ferrous ion reaction. Trans Faraday Soc. 1951;42:155-169.

7 Walling C, Weil T. Int J Chem Kinet. 1974;6:507-516.

8 Bray WC, Gorin MH. Ferryl ion, a compound of tetravalent iron. J Am Chem Soc. 1932;54:21242125 .

9 Buda F, Ensing B, Gribnau MCM, Baerends EJ. DFT Study of the Active Intermediate in the Fenton Reaction. Chem Eur J. 2001;7:2775-2783.

10 Enami S, Sakamoto Y, Colussi AJ. Proc Nat Acad Sci. 2014;111:623-628.

11 Kohn W, Sham LJ. Phys Rev A. 1965;140:1133-1138.

12 Tsuneda T. Density Functional Theory in Quantum Chemistry. Tokyo: Springer; 2014.

13 Tsuneda T, Hirao K. WIREs Comput Mol Sci. 2014;4:375-390.

14 Iikura H, Tsuneda T, Yanai T, Hirao K. A long-range correction scheme for generalized-gradientapproximation exchange functionals. J Chem Phys. 2001;115(8):3540-3544.

15 Becke AD. Phys Rev A. 1988;38:3098-3100.

16 Lee C, Yang W, Parr RG. Development of the Colle-Salvetti correlation-energy formula into a functional of the electron density. Phys Rev B. 1988;37:785-789.

17 Tawada Y, Tsuneda T, Yanagisawa S, Yanai T, Hirao K. J Chem Phys. 2004;120:8425-8433.

18 Tsuneda T, Singh RK, Iiyama A, Miyatake K. ACS Omega. 2017;2:4053-4064.

19 Tsuneda T, Miyake J, Miyatake K. ACS Omega. 2018;3:259-265.

20 Dunning Jr TH. Gaussian basis sets for use in correlated molecular calculations. I. The atoms boron through neon and hydrogen. J Chem Phys. 1989;90:1007-1023.

21 Kendall RA, Dunning JTH, Harrison RJ. Electron affinities of the first-row atoms revisited. 
Systematic basis sets and wave functions. J Chem Phys. 1992;96:6796-6806.

22 Hay PJ, Wadt WR. J Chem Phys. 1985;82:299-310.

23 Tomasi J, Mennucci B, Cammi R. Chem Rev. 2005;105:2999-3093.

24 Peng C, Schlegel HB. Combining Synchronous Transit and Quasi- Newton Methods to Find Transition States. Israel J Chem. 1993;33:449-454.

25 Peng C, Ayala PY, Schlegel HB, Frisch MJ. Using redundant internal coordinates to optimize equilibrium geometries and transition states. J Comput Chem. 1996;17:49-56.

26 Maeda A, Harabuchi Y, Ono Y, Taketsugu T, Morokuma K. Int J Quantum Chem (Special Issue: Theoretical Chemistry in Japan). 2015;115:258-269.

27 Hratchian HP, Schlegel HB. Accurate reaction paths using a Hessian based predictor-corrector integrator. J Chem Phys. 2004;120:9918-9924.

28 Hratchian HP, Schlegel HB. Using Hessian updating to increase the efficiency of a Hessian based predictor-corrector reaction path following method. J Chem Theory Comput. 2005;1:61-69.

29 Bauernschmitt R, Ahlrichs R. Chem Phys Lett. 1996;256:454-464.

30 Seeger R, Pople JA. J Chem Phys. 1977;66:3045-3050.

31 Frisch MJ, Trucks GW, Schlegel HB, Scuseria GE, Robb MA, Cheeseman JR, et al.. Gaussian09 Revision D.01; 2009. Gaussian Inc. Wallingford CT.

32 Dennington R, Keith T, Millam J. GaussView, Version 5; 2009. Semichem Inc., Shawnee Mission KS.

33 Hiroki A, LaVerne JA. J Phys Chem B. 2005;109:3364-3370.

34 Giguerre PA, Liu ID. Can J Chem. 1957;35:283-293.

35 Kijewski H, Troe J. Int J Chem Kinet. 1971;3:223-235.

36 Tessier A, Forst W. Can J Chem. 1974;52:794-797.

37 Baulch DL, Cobos CJ, Cox RA, Frank P, Hayman G, Just T, et al. J Phys Chem Ref Data. 1994;23:847.

38 Gray P. Trans Faraday Soc. 1959;55:408-417.

39 De Laat J, Gallard H. Environ Sci Technol. 1999;33:2726-2732.

40 Evans RW, Rafique R, Zarea A, Rapisarda C, Cammack R, Evans PJ, et al. J Biol Inorg Chem. 2008;13:57-74.

41 Nishida Y. The Chemical Times (Japanese). 2015;236:8-16.

42 Marcus RA. Rev Mod Phys. 1993;65:599-610. 
43 Chandler D. Electron transfer in water and other polar environments, how it happens. In: Berne BJ, Ciccotti G, Coker DF, editors. Classical and Quantum Dynamics in Condensed Phase Simulations. Singapore: World Scientific; 1998. p. 25-49. 